\title{
沖積低平地に立地する城下町都市佐賀における水路の空間特性に関する考察 A STUDY ON THE SPECIFIC SITUATION OF WATERWAYS IN THE CASTLE TOWN SAGA LOCATED IN LOWLAND ALLUVIAL PLAINS
}

\author{
後藤 隆太郎*, 中 岡 義 介** \\ Ryutaro GOTO and Yoshisuke NAKAOKA
}

\begin{abstract}
This study aims to clarify the specific situation of waterways in the castle town Saga, focussing on their sustainable development. The results are as follows: 1) Waterways are specific fundamentals entirely necessary to the development of the town in lowland alluvial plains. 2) Existing waterways are built in the former castle town area with the basic and sustainable network repeating the pattern of waterway-road. 3) Existing waterways serving only as the enclosure of the social settlement unit can be divided into two types of meanings for the town life; the communal and personal availability. 4) Visibility to waterways essential for the future development will be obtained from two types of place; view from spots and linear view.
\end{abstract}

Keywords : Lowland Alluvial Plain, Castle Town Saga, Waterways Bult in the Town, Settlement with Waterways, Visible Condition of Waterways 沖積低平地、城下町都市佐賀、都市の中の水路、水路と居住、水路の見え方

はじめに

わが国の主要な現代都市の多くが近世城下町に基礎をおいている

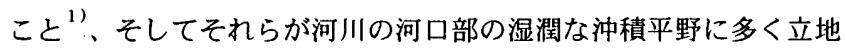
しているこどは指摘されて久しい。前者は日本の諸都市に同質性 をもたらしたと考えることができるが、後者は、城下町形成におい て水をいかに制御するかということと同時に、水をいかに都市生活

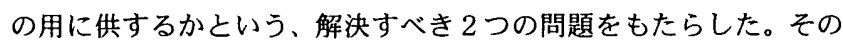
結果、城下町にもたらされたものが水路である ${ }^{3)}$ 。そうした水路の あり方は城下町によって異なるが、沖積低平地に立地した佐賀の城 下町は水路をかなり密に張り巡らして構想されたものの一つである。

このような城下町を起源とする都市がさまざまな理由で水路を見 えなくさせあるいは消滅させていったこと市もすでに指摘されて久 しいが、そうした中にあって城下町都市佐賀（城下町を起源として 展開した現佐賀市の市街化区域内とし：以下佐賀とする）では、か つて城下町であった部分（以下、旧城下町とする）において水路が かなりの密度を保っているばかりでなく、市街地の拡大も水路を保 持しつつ行われている。

このような佐賀の水路について、宮本 ${ }^{5)}$ や波多野 ${ }^{6)}$ の都市史的研 究等の既往研究が着目される。しかし、意外なことに、今なお密に 存在するにもかかわらず、水路の現状について詳細に言及したもの
は管見の及ぶ限り皆無である。このことは、現在の佐賀の人々の水 路への関心の薄さとも深くかかわっている。もともと水路は日常生 活において主に用水と悪水として利用されていたが、まず上水道の 敷設と普及によって上水としての機能から開放され、下水路として の役割も下水道整備によって大きく後退することとなった。また、 毎年繰り返されていた増水も後背山地のダムや河口部の排水ポンプ 場が完成するなどによって大きく減少することとなった。それらの 結果、市街地の水路の常水量はかなり少なくなり、人々の水路への 関心は、水路の多くが宅地背後にあることとあいまって、多少の自 主的維持管理以外は極端に薄らいでいるといえる。その一方で、域 内河川一堀川・クリークー江湖による水系として水路があること、 低平地ゆえに増水時の調整機能を水路が有していることなどのため、 水路不要論といったものは生じておらず、利用することなくあるが ままの水路をなかば無意識的に受け入れているのが現状である。

このような現状の水路の整備をうながす契機は今のところ顕在化 していないといってよい。しかし、今のままでは水質の悪化による 水路の是非や都市の活性化による水路の宅地化などの問題が生じる のは必至で、それまで手をこまねいて待っているわけにはいかず、 整備の必要性をうながす方途を考えねばならない。そのためにはい くつかの方法が考えられるが、佐賀の水路が歴史的存在であること
* 佐賀大学理工学部都古工学科 助手 $\cdot$ 工修

** 兵庫教育大学生活健康系教育講座 教授・工博
Research Assoc., Dept. of Civil Engineering, Faculty of Science and Engineering, Saga University, M. Eng.

Prof., Division of Practical Life Studies, Hyogo University of Teacher Education, Dr. Eng. 
に着目し、それが現在、空間的によ゙のように継承されているかをみ ることによって水路の空間価値を明らかにし、日常的な利用はされ ていないものの水路が生活といかにかかわって現存しているか、そ の生活とのかかわりが空間としての水路を変えようとしているかど うかを見極め、そのような水路を人々の意識にのほらせる方法とし て、人々が水路にかかわるもっとも初期のものの一つと考えられる 水路が見えるか見えないかを取り上げてその可能性を検討してみた W。

かかる観点から、本研究では、まず、佐賀の旧城下町において（I ） どのような種類の水路がどれほどあるのか、佐賀における水路の基 礎的事項を明らかにする。その上で、（II）そのような水路が都市に どのように組み込まれているのか、都市と水路の空間的関係を明ら かにする。次に、そうした都市空間の中で、(III) 都市生活がいかに 展開されているのか、個々の社会的居住単位を取り上げて都市と水 路の生活的関係を明らかにする。さらに、(IV) 高密度に張り巡らさ れた佐賀の水路は都市を行動する人々にいかに認識されうるのか、 都市と水路の視覚的関係を明らかにする。なお、ここで用いた資料 は1991〜1992 年度に行った調査 ${ }^{7)}$ によるものである。

\section{1. 城下町都市佐賀の概要}

現在の佐賀市は、図ー1に示すように有明海の湾奥部の広大かつ平 坦な蚝積低平地に位置している。ここでの水系システムは、後背山 地から流れる嘉瀬川をはじめとする中小河川を主な水源とし（図一 2)、田園地域には河川・農業用水路を介してほ場等に配され、張り 巡らされたクリーク（図-3）から佐賀江などの干潮河川（江湖）に 排水される。一方の旧城下町には主に近世初頭につくられた石井嗵 や多布施川から城下や城内の堀川に配され、同じく干潮河川などに 排水され、最後には嘉瀬川や有明海に通じている ${ }^{8)}$ 。また、ここでは きわめて低地であることや有明海の満潮時の逆潮の影響により増水 時の排水がきわめて困難であり、全域に張り巡らされたクリークや 堀川などは貯水地としての役割をもち、今日においても洪水調整の 大きな役割を担うとされる。

このような水利的な環境における現在の市街地は、堀川とともに 建設された旧城下町を中心として、かつての田園や集落 のクリーク網をそのまま利用して形成された市街地（以 下、田園市街地とする)、及び田園地域に部分的に行われ た土地区画整理事業などによる近年の計画的市街地（以 下、計画市街地とする)によって構成されている (図-1)。

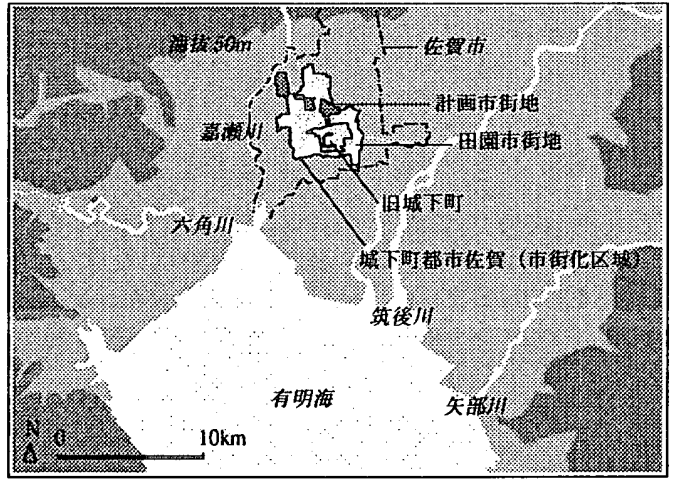

图 - 1 城下町都市佐賀の位置

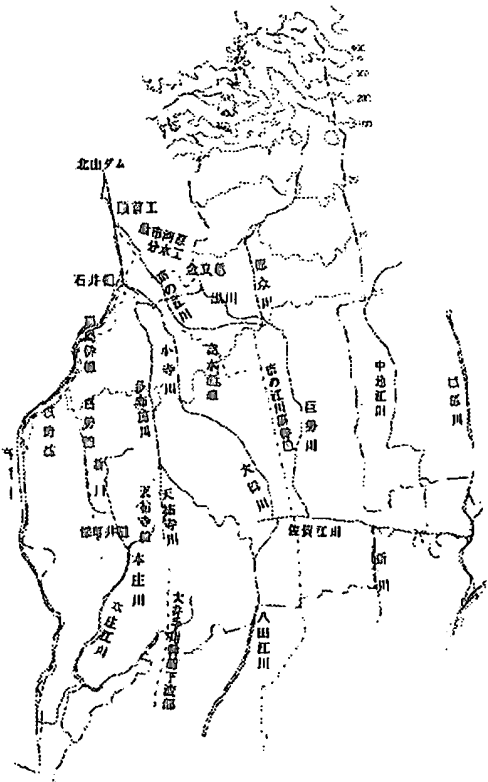

图 - 2 市域水系・農業水利幹稀凶

\section{2. 水路の状況}

本章では旧城下町の水路の定量的把握を行う。そのさい、旧城下 町の水路の状況を現在の市街地において位置づけるために、市街化 区域内の田園市街地之計画市街地の各地域についても比較对象とし て取り上げる。調㚗項目は水路の種類と水路面積 ${ }^{9}$ ) および後述する 水路空間である。調查・集計は町丁目を単位として、旧城下町は 35 町丁目、田園市街地は 84 町丁目、計画市街地は 14 町丁目、合計 133 町丁目の市街地全域について行った ${ }^{10)}$ 。

\section{9 水路の種頻}

佐賀には龧川、川、クリークと呼び慣わされている水面がある。堀 川とは主に旧城下町でみられるもので、幅が一定なものが多い。川 とは法的に河川と称されるものである。クリークとは村落や農業に 深くかかわって存在してきたもので、不定形な形をしたものが多い。 本稿ではこのような現在の市街地にみられる水面を総称して“水路” と呼ぶことにする゙'。

以上の市街地全域の水路は、調査の結果、次の 4 つに区分するこ とができた。すなわち、(1)幅 $1 \mathrm{~m}$ 末満の一定幅の水路（以下、1m 末 満の水路とする)、(2)幅 $1 \mathrm{~m}$ 以上の一定幅の水路（以下、 $1 \mathrm{~m}$ 以上の水 路とする)、(3)河川、(4)クリークである。一定幅の水路を 2 種類に分

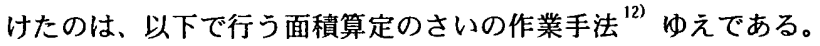

\section{2 水路面嘳・水路の有無・水面华の実態}

\subsection{1 水路面䅬}

調査・集計の結果、旧城下町の水路総面積は約 28 万 $\mathrm{m}^{2}$ であった。 旧城下町でもっとも面積が多い水路の種類は $1 \mathrm{~m}$ 以上の水路であり、 面積 25.0 万 $\mathrm{m}^{2}$ (全体比 $89.8 \%$ ) とほとんどをしめ、次いで河川 1.2 万 $\mathrm{m}^{2}(4.3 \%) 、 1 \mathrm{~m}$ 末満の水路 1.1 万 $\mathrm{m}^{2}(3.8 \%) 、 ク リ ー ク 0.6 万 \mathrm{~m}^{2}(2.1 \%)$ の順となっている。

\subsection{2 水路の有無}

旧城下町において、水路をまったくもたない町丁目や一定幅の水 路をもたない町丁目はなく、このことは田園市街地、計画市街地に おいても同様であった。そこで、町丁目ごとに水路の種類がどのよ うにあるのかを、水路の種類の地域比較として図ー4に示す。旧城 下町では、一定幅の水路のみが 25 町丁目と多く、残る 10 町丁目で 
一定幅の水路に加え河川、クリーク、又はその両方がある。計画市 街地では、旧城下町と同様に一定幅の水路のみが多く、田園市街地 ではクリークがある町丁目が比較的多くなっている。

したがって、旧城下町の水路はほとんどが一定幅の水路であり、 一部に田園市街地に多いクリークや河川が加わったものである。

\subsection{3 水面率}

次に、水路面積が占める割合をみるために水面率 ${ }^{137}$ を算出した。旧 城下町全体の平均水面率 ${ }^{13)}$ は $5.7 \%$ であり、市街地全域の平均水面率 $5.1 \%$ よりも高い。町丁目ごとの水面率を図一 5 にみると、旧城下町 では城壕が存在するため、10\%以上といった水面率が特に高いもの が 4 町丁目あるが、それらを除くと水面率 $4 \sim 6 \%$ 末満が 10 町丁目、 同 2 4\%末満が 15 町丁目と、水面率が低い町丁目が多い。田園市 街地では水面率が高いものから低いものまであり、計画市街地は水 面率が低い町丁目がほとんどである。

したがって、旧城下町では城壕などがある水面率が高いいくつか の町丁目と、そのほかの水面率が低い町丁目がある。また、このよ うな町丁目ごとの水面率のばらつきは、田園市街地にも同じくみと められるが、計画市街地では水面率が特に高い町丁目はなく、水面 率が低い町丁目が多くなっている。

\section{3 水路空間の実態}

次に、このような水路が都市の中にどのような形で存在している のか、水路の存在形態を明らかにする。具体的には、1）水路の護 岸構造からその整備状況をみる指標として水際の状況、2）水路が 空間的・視覚的に開かれているのか、また閉ざされているのかをみ る指標として境界の状況、3）都市の中の水路がどのような空間を もたらしているのかをみる指標として沿川利用 ${ }^{14)}$ の状況、これら 3 要素からなる空間を水路空間 (図一6) と称して、それぞれ調査をお こなった ${ }^{15)}$ 。

\subsection{1 水際の状況}

水際はコンクリート、石垣、土堤、その他の 4 つに分類すること ができ、旧城下町におけるそれらの距離数を整理すると、コンク
リートが $40.1 \mathrm{~km}$ (全体比 $50.7 \%)$ ，石垣が $32.1 \mathrm{~km}(40.6 \%)$ と多く、次 いで土提 $6.5 \mathrm{~km}$ (8.2\%)、その他 $0.4 \mathrm{~km}(0.5 \%)$ の順となっている。

次に、各町丁目において、もっとも多い水際の種類を代表的な水際 として、地域ごとに図ー7に示す。旧城下町では、田園市街地や計画 市街地にほとんどみられない石垣が代表的な水際となる町丁目が 18 、 コンクリートが 17 町丁目である。一方、田園市街地と計画市街地で は、旧城下町にはみられない土提が代表的な水際となる町丁目がいく つかあるが、コンクリートがほとんどを占めている。

\subsection{2 境界の状況}

境界は、建物やブロック塀などの水路への視界が遮られる非可視的 構築物、ガードレールやフェンスなどの可視的構築物、樹木や生け垣 などの自然物、構築物なし、その他に分類することができた。旧城下 町においてそれらの距離数を整理すると、非可視的構築物が $26.2 \mathrm{~km}$ (34.4\%)、可視的構築物が $20.7 \mathrm{~km}(27.2 \%)$ と多く、次いで自然物が $14.5 \mathrm{~km}$ (19.0\%)、構築物なしが $14.5 \mathrm{~km}$ (19.0\%)、その他が $0.3 \mathrm{~km}(0.4 \%)$ の順となっている。

次に、各町丁目においてもっとも多い境界の種類を代表的な境界と して、地域ごとに図ー8に示す。旧城下町では非可視的構築物が代表 的な境界となる町丁目が19 と、田園市街地、計画市街地と比べて多く なっている。一方、可視的構筑物は 10 、自然物は 3 、構築物なしは 3 であり、水路を空間的にも視覚的にも完全には区切らない境界が代表 的となる町丁目も少なくない。

\subsection{3 治川利用の状呮}

水路沿いの主たる土地利用を沿川利用として、私的建物、駐車場、 空地、生産緑地、公園・神社、公的建物、道路、その他に分類するこ とができた。旧城下町においてそれらの距離数を整理すると、私的建 物が $45.5 \mathrm{~km}$ （全体比 $59.0 \%$ ）ともっとも多く、次いで道路が $12.6 \mathrm{~km}$ (16.2\%)、駐車場 $5.7(7.4 \%)$ 、公的建物 $4.3(5.5 \%)$ 、公園神社 $4.2(5.4 \%)$ などとなっている。

次に、各町丁目においてもっとも多い沿川利用の種類を代表的な沿 川利用とし、地域ごとに図ー9に示す。旧城下町では私的建物が代表

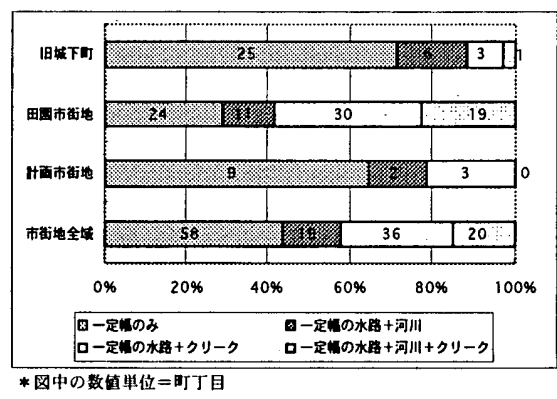

図 -4 町丁目別水路の種類とその地域比較

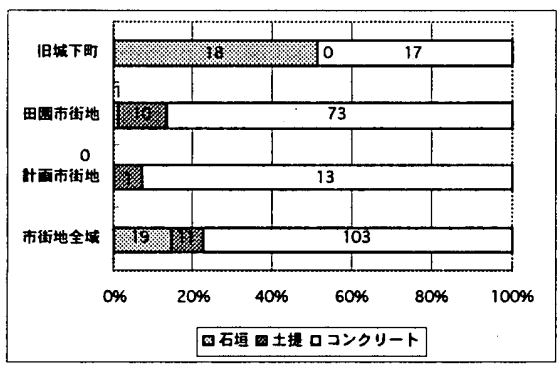

*图中の数直策位二旷丁目

図 -7 町丁目別代表的な水際とその地域比較

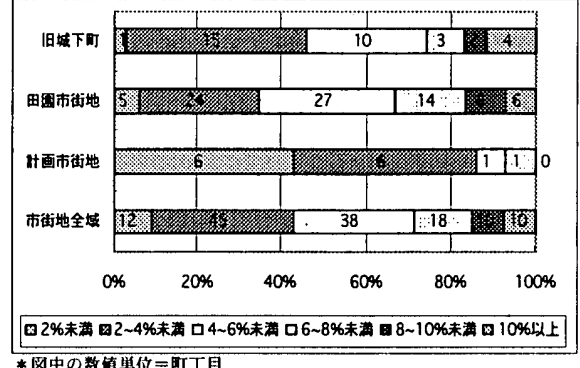

図-5 町丁目別水面率とその地域比較

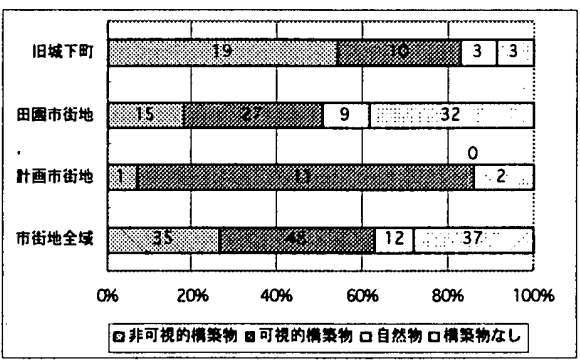

*图中の數直単位 $=$ 町丁目

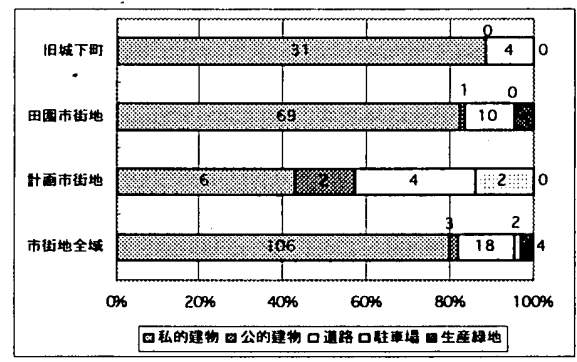

*図中の数值単位二时T目

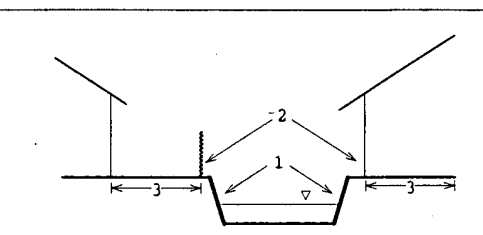

1:水際の状況、2:境界の状況、3:沿川利用の状況

図 -6 水路空間の概念図

-9 町丁目別代表的な沿川利用とその地域比較 
的な沿川利用となる町丁目が 31 とそのほとんどを占める。田園市街 地と計画市街地においても私的建物が多くなっているが、計画市街 地では道路が代表的な沿川利用となる町丁目が他の地域と比べて多 W。

\subsection{4 水路空間としてみた水路の状況}

以上のように、旧城下町の水路空間をとらえると、石垣やコンク リートによって多くの護岸が整備されていること、水路は公的な空 間よりも私的な空間とともに多くあること、水路を空間的・視賞的 に分断しない境界も少なからずあることなどをみとめることができ る。また、田園市街地と計画市街地では、土提が一部にみられるも のの主にコンクリートによって多くの護岸が整備されていること、 水路を空間的・視覚的に分断しない境界が旧城下町と比べてより多 いこと、さらに、田園市街地では城下町と同様に私的な空間が水路 とともに多くあり、一方の計画的市街地では公的な空間が水路とと もに比較的多くあることなどをみとめることができる。

\section{3. 地割パターンからみた都市と水路の空間的関係}

本章では、現在の水路が都市の中に空間的にどのように組み込ま

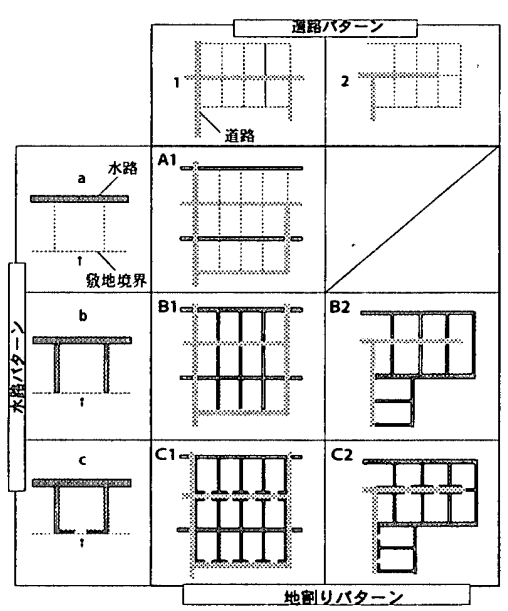
れているのかを明らかに する。現在の水路は変貌 の積み重ねの結果として 存在するととらえること ができるから、まず、ほぼ 確立した城下町佐賀が詳 細に描写されている、承 応三年 (1654) の「佐賀城 趈之絵図」(以下、絵図)を
取り上げ、そこで見られる都市と水路の空間的関係として地割パター ンを抽出する。次に、それがいかに変化して現在にいたっているのか をみることによって、現在における地割パターンを抽出する。

\section{1 城下町絵図にみる地割パターン}

絵図には、水路、道路、敷地（屋敷地）割が詳細に記入されている。 その水路と敷地、道路と敷地の組み合わせから、水路パターン 3 分 類、道路パターン 2 分類を見いだすことができ、それらの水路パター ン・道路パターンの組み合わせとして、図ー10のように 5 つの地割 パターンに整理することができた。このような地割パターンの分布を 現在の地形図にあてはめると図－11のようになる。図中の英数字は 各地割パターンを示し、ははパターンが混在することを、()は部分的 にみられることを示している。また、地割パターンの境界は一部は道 路に重なるが、ほとんどは水路に該当している。

地割パターンA1は、敷地奥のみの水路パターン $\mathrm{a}$ と行き止まりを もたない道路パターン 1 の組み合わせであり、城内の北、東側の武家 地にみられた。地割パターン $\mathrm{Al}$ ' は絵図に䋖部が描かれていない町 人地の部分であり、他の絵図などからパターンA1 と同様と判断した ものである。なお、この Al' の町人地を除いた部分は基本的に武家 地である。地割パターン B1 は、敷地奥と敷地横に水路がある水路パ ターンbと道路パターン 1 の組み合わせであり、主に東側の武家地に みられる。地割パターン $\mathrm{C} 1$ は、水路が敷地を取り囲んでいる水路パ ターンcと道路パターン 1 の組み合わせであり、城下町の西側と東側 の一部にみられる。

地割パターン $\mathrm{B} 2$ および $\mathrm{C} 2$ は、水路パターン $\mathrm{b}$ おび水路パターン c と行き止まりの道路を含む道路パターン 2 の組み合わせである。パ ターン $\mathrm{C} 2$ が東端部にみられ、パターン $\mathrm{B} 2$ と $\mathrm{C} 2$ が混在する部分が城 下町の南側にみられ、概ねパターン B 2 と 2 は城下町周縁の南・東側

図 -10 絵図にみる水路・道路パターン及び地割パターン

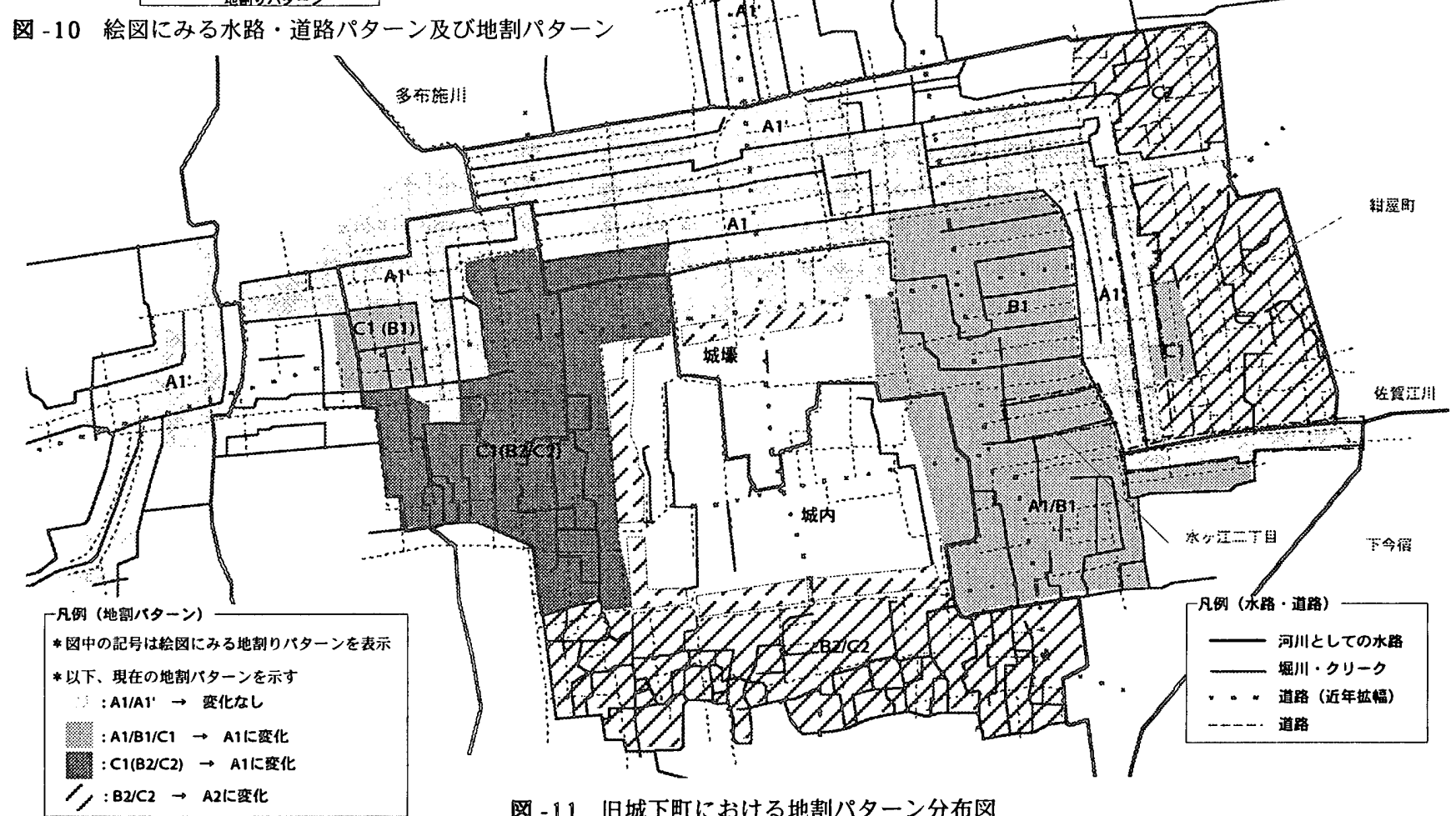

図－11 旧城下町における地割パターン分布図 
にみることができる。これらは、水路や道路に非直線的なものがみ られることや敷地の大きさが均一ではないなど、やや複雑な形態的 特徽をもつ。

\section{2 現在の地割パターン}

次に、上述した絵図にみられる地割パターンがどのように変化し て現在にいたっているのかを、現地及び現状地形図で確認すること で明らかにした。その結果（図ー11）、絵図による地割パターンB1 及びC1は、敷地の横や前面の道路沿いにあった水路が消失し敷地奥 の水路のみが残されることで、おおむねパターン A 1 に変化してい る。地割パターン B2 とC2についても敷地の横や前面の道路沿いに あった水路が部分的に消失し、やや複雑に変化する傾向があるもの の、かつてはみることができなかったA2に概ね変化している。なお、 道路については部分的な変化がみられるものの、大幅な変化はみら れない。

以上のことから、現在の旧城下町は、おおむね敷地を挟むように 水路と道路が交互に繰り返されるA系のタイプに集約されていると いえる。そ扎らに $\mathrm{C}$ 系、B系から A 系のタイプに変化した部分も 多く含まれるが、その場合にも、各敷地の横や前面などの末端の水 路は消失したものの敷地奥の水路は基本的に残っているように、水 路と道路が交互に繰り返されるといった、骨格となる構成は基本的 に変化していないとみることができる。

\section{4. 社会的居住単位の展開}

次に、このような都市のなかで、都市生活がいかに展開されてい るのか、都市と水路の生活的関係を明らかにする。ここでは、都市 と水路の関倸解明であることに鑑み、個々の水利用に着目するので
はなく、社会的居住単位を取り上げ、その空間実態から社会的居住 単位が水路とどのように関わって形成されているのかをみることに する。

具体的には、前章でみた現在の代表的な地割パターン $\mathrm{A} 1$ のなか で、社会的な居住のまとまりが認められる3 地区を取り上げて ${ }^{16)}$. （1）地区における管理的表現として住民組織の実態、（2）地区に おける生活の空間的表現として水路及び道路利用の実態、(3) 地 区における個々の生活の空間的表現として敷地利用の実態を明らか にする ${ }^{17) 。}$

\section{1 社会的居住単位の空間実態}

\subsection{1 紺屋町の空間構成}

(1) 地区の概要 : 紺屋町は、現在の行政上の住居表示では紺屋町と 東佐賀町の一部に分かれているが、藩政時代は町人地に属した一つ の町であり、現在もこの紺屋町が一つの自治会となっている社会的 居住単位である。このような地区の空間的な範囲は図ー12となって おり、中央の道路を中心とした両側町は、おおむね東、西と南側の 水路によって隣接する地区と隔てられている。

(2) 住民組織: 紺屋町の自治会は 26 班で構成し、図一 12 では網掛け の違いによって各班の範囲を示している。道路をまたぐものが8班 あるが、水路をまたいでいる班はみられない。

(3) 水路及び道路の利用: 図一 13 をみると、西側の水路の水際およ びそれに沿った道路には、洗濯物干し台が 4 力所、個人宅用のゴミ 箱が 2 力所、えびすと地藏がそれぞれ 1 力所、共用栓 ${ }^{18)}$ が 2 力所、 可然物及び資源物・不燃物ゴミテーションの看板が合わせて 12 力所確認でき、公的な存在である道路や水路であるにもかかわらず 個人的な利用のための要素が少なからずある。一方、中央の道路に
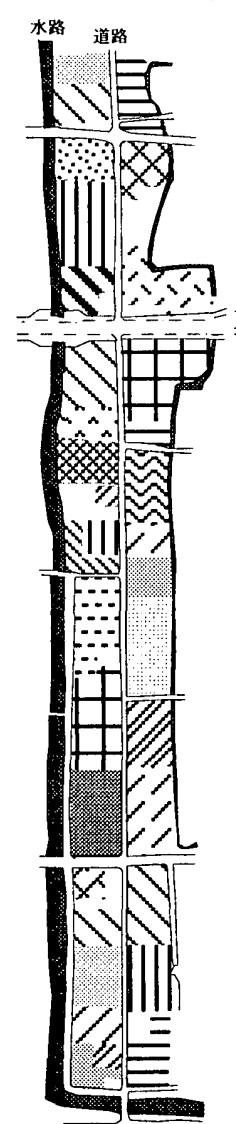

図-12 紺屋町の 住民組織
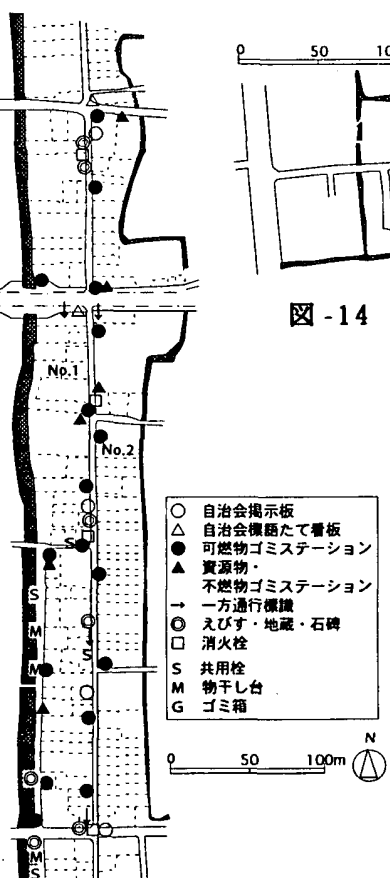

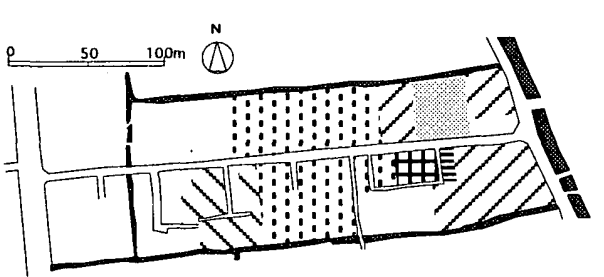

-14 水ヶ江二丁目会所小路の住民組織

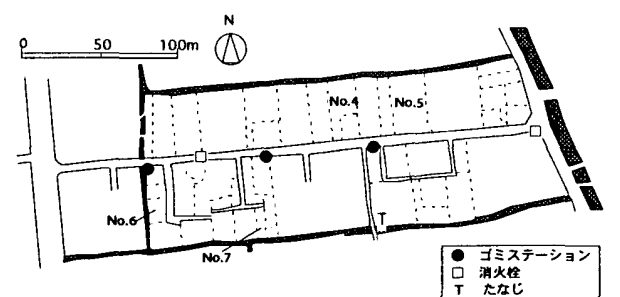

図 -15 水ヶ江二丁目会所小路の水路・道路の利用

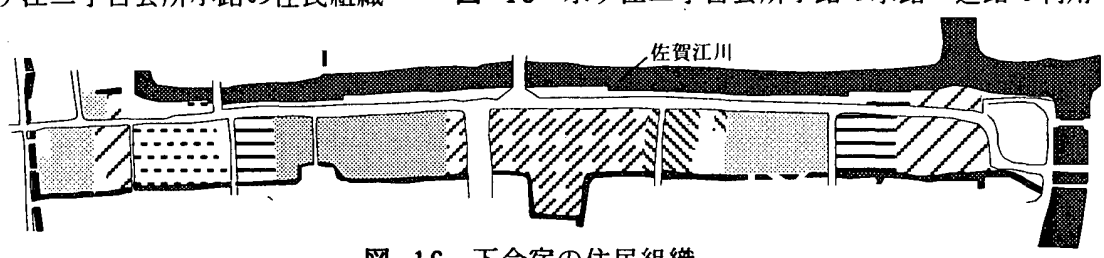

図 -16 下今宿の住民組織

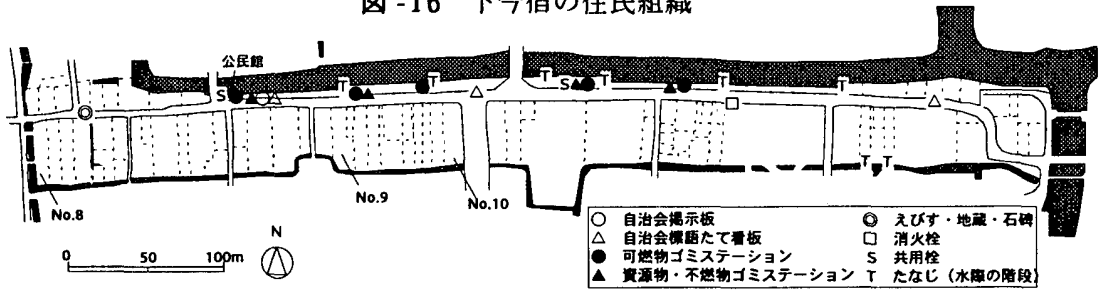

図-17 下今宿の水路・道路の利用
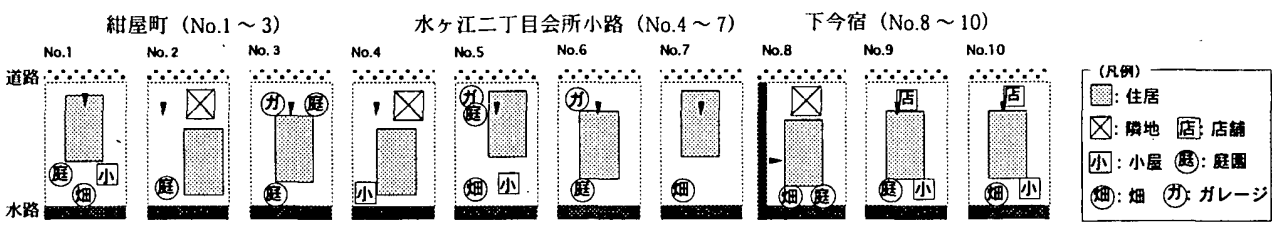

図-18 各敷地利用の模式図 
は自治会の掲示板や標語たて看板が 8 力所、えびすが 6 力所、消火 栓が 3 力所、一方通行の標識が 3 力所、共用栓が 3 力所、可燃物及 び資源物・不矩物コミステーションの看板が 21 力所確認でき、地 区において共同で利用される要素が多くある。

(4) 教地利用 : 地区内のいくつかの敷地を対象として敨地の利用調 査を行い、その結果を模式的に図一 18 (No.1〜3) に示す。水路側 には住宅、庭園、畑、小屋があり裏庭的な空間がみられる。道路沿 いにはカレージや庭園、住宅へのアプローチがみられる。

\subsection{2 水ヶ江二丁目会所小路の空間篗成}

(1) 地区の概要:水ヶ江二丁目会所小路は、現在の住居表示では水ヶ 江二丁目の一部であり、そのなかの一本の道路を中心とした居住の まとまりが古くから会所小路と呼ばれている一つの社会的居住単位 である。この地区の空間的な範囲は図ー 14 となっており、水路に よって隣接する地区と隔てられている。この地区は前章でみた地割 パターンがB1から $\mathrm{A} 1$ に変化したかつての武家地である。かつて各 政地の横にもあった水路は、地区の周囲を除いてすべて消失してい るが、その消失した水路の位置が現在の影地境界線となっていると ころが多い。

（2）住民組織：この地区は、北水ヶ江という自治会に属し、図－14 にしめすように 7 班で構成されている。そのうち道路をまたぐもの が 3 班あるが、水路をまたいでいる班はみられない。

(3) 水路及び道路の利用 : 図ー15をみると、水路にたなじ（階段状 の水に近づくための装置) が 1 力所みられ、個人的に水路を利用す る要素が確認できる。道路には、ゴミステーションの看板が 3 カ 所、道路の両端近くに消火栓が 2 力所と、地区住民のための要素が みられる。

(4) 敷地利用 : 図一 $18(N o .4 〜 7)$ をみると、水路側には住宅、小 屋、㚼、庭園などがあり、裹庭的な空間がみられる。道路沿いには カレージや住宅へのアプローチなど、外部との接触空間がみられ る。

\subsection{3 下今宿の空間構成}

(1) 地区の概要 : 下今宿は、現在の行政上の住居表示では朝日町の 一部および今宿町の一部となっているが、藩政時代は町人地に属し た一つの町であり、現在も一つの自治会としてある。この下今宿の 空間的な範囲は図ー16となっており、地区は佐賀江川に北面し、お おむね水路によって瀿接する地区と隔てられている。

（2）住民組織：この地区の自治会は図ー16に示すように10班で構成 されており、東および西側の5班は道路をまたいでいるが、水路を またいでいる班はみられない。

(3) 水路及び道路の利用: 図一 17 をみると、北側の佐賀江川沿いは かつての船着き場であった「縁場」とよばれる場所であり、水際に 6 力所のたなじが確認でき、西端に公民館がある。一方の南側水路 の水際には、たなじが2力所確認できた。道路には、可燃物及び資 源物・不㜣物ゴミスーションの看板が 7 カ所あり、自治会の掲示 板やえびす・地蔵・石碑、2つの共用栓がある。

(4) 敨地利用 : 図一 18 （No.8〜 10）をみると、水路側には小屋、庭 園、姆があり、各影地の個別的な利用や裹庭的な空間がみられる。 道路沿いには店舗や住宅へのアプローチなど、外部との接触空間が みられる。

4.2 社会的居住単位と水路の閶係
以上の調查結果から、次のような社会的生活単位と水路との関係 を抽出することができる。

まず第 1 に、ここで取り上げた社会的居住単位の空間的な範囲は、 いずれも水路によって囲まれあるいは境界づけられている。地区内 の班といったより小さな社会的単位をみても、地区の道路をまたぐ ことはあっても水路を越えるものはない。つまり、水路が隣接する 地区を隔てることによってそれぞれの地区は成り立っている。

第 2 にこのような社会的居住単位の空間は図ー19のようにいず れも二つの部分からなる。I の部分は道路 (下今宿の場合は水路も) と住居接道部があって地区の外部との接触空間となり、地区住民の 共有空間もここに設けられる。ここには地区の情報の場としての自 治会揭示板や生活基盤施設としてのゴミステーションなど、地区で の生活装置が多く存在する。II の部分は住宅、㚼、庭園といった個 人的日常生活の場と住居生活のはみ出しがみられる水際・水路であ る。

第 3 にここでみられる水路は二種類に分けられる。一つは、下 今宿のI の部分、道路に沿った水路にあらわれているもので、かつ ての水運荷揚場で今日においても共同性を強くもち、また外部との 接触空間ともなっている、「外に向く水路」ともいうべきものであ る。もう一つは、紺屋町、水ヶ江二丁目会所小路及び下今宿の II の 部分、教地奥の水路にあらわれているもので、公的存在であるはず の水路が個々の日常生活とかかわることで私的性格の強い空間と なっている、「内に向く水路」ともいうべきものである。

\section{5. 水路の見え方の实態}

次に、高密度に張り巡らされた佐賀の水路が都市を行動する人々 にどのように見えるのか、都市と水路の視覚的関係を明らかにする。 水路はおのずとそこで行動する人々になんらかの形で認識される対 象となる。その認識の初期的な一つとして視覚的な認識がある。水 路が人々の目につくかということである。そこで、水路が都市の中 でどのように見えるかを調査した。調查の項目は、水路の見える場 所であり、見える場所とは誰もが自由に立ち入ることができる沿川 で、その前面に水路が開けているところとした。調査対象は旧城下 町、及び比較対象としての田園市街地と計画市街地である。

\section{1 可視非}

まず、水路の見える場所がどれ程あるのか、その量的状況をみる。 町丁目の大きさが異なるから、町丁目ごとの水路の見える場所の総 距離数をみるのではなく、水路の見える割合を取り出すことにする。 ここでは、水路の見える場所の総距離数/沿岸利用の総距離数でも とめ、それを可視率とする ${ }^{19)}$ 。旧城下町の平均可視率 ${ }^{199}$ は $28.1 \%$ で あり、田園市街地 (31.1\%)、計画市街地 (41.1\%)、市街地全域 (31.4\%) と比べてやや低いが、地域ごとに大きな違いはない。

各町丁目の可視率について、地域ごとに整理して図ー20に示す。 旧城下町では可視率 $20 \%$ 未満が合計 13 町丁目、20〜 40\%未満が合

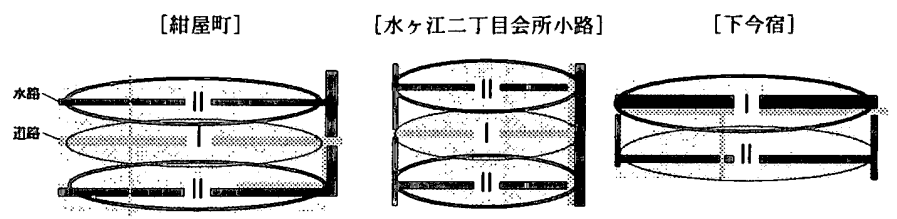

图 -19 社会的居住単位の空間特性 
計 13 町丁目、 $40 \%$ 以上が合計 9 町丁目と、可視率が高いところから 低いところまである。このような可視率のばらつきは、田園市街地に おいても旧城下町と同様にみとめることができ、計画市街地では可視 率 40\%以上といった可視率が高いところが多くなっているが、同じ く可視率のばらつきをみとめることができる。

\section{2 水路の見える場所（距離数）}

水路の見える場所は、道路、橋（私橋を除く）、駐車場、空き地、公 園・神社、水路の端、公的施設、行き止まり、とその種類を区分する ことができた。それらを距離数で整理すると、旧城下町では、道路が $12.4 \mathrm{~km}$ （全体比、57.4\%）ともっとも多く、次いで公園・神社 $3.2 \mathrm{~km}$ (14.6\%)、駐車場 $2.5 \mathrm{~km}(11.5 \%)$ 、橋 $2.3 \mathrm{~km}(10.7 \%)$ 、公的施設 $0.6 \mathrm{~km}$ (2.7\%)、空き地 $0.6 \mathrm{~km}$ （2.6\%）などとなっている。

各町丁目において、これらのもっとも多い種類を代表的な見える場 所 (距離数) として図ー21に示す。旧城下町では道路が 24 町丁目と 多くなっているが、駐車場が 5 、橋が 4 、公園・神社と公的施設がそ れぞれ1町丁目づつあり、道路以外が代表的な水路の見える場所（距 離数）となるものも少なくない。一方、田園市街地と計画市街地にお いては、道路が代表的な水路の見える場所（距離数）となる町丁目が ほとんどである。

\section{3 水路が見える場所（個所数）}

水路の見える場所としての道路は、線的な存在である。それに対 し、橋、駐車場、公園・神社、公的施設などは点的な存在である。点 的な場所が代表的な水路の見える場所となっているということは、水 路が見えるかどうかということの検討には、距離数だけでなく、個所 数も重要であることを示している。そこで、水路の見える場所を個所 数で整理 ${ }^{20)}$ すると、旧城下町では合計916力所を確認することができ る。そのうち橋が 497 力所（全体比、54.3\%）ともつとも多く、それ に次いで、道路が 208 力所 (22.7\%)、駐車場が 104 力所 (11.4\%)、数 は少なくなるが水路の端が 30 力所 $(3.3 \%)$ 、公園・神社が 30 力所 (3.3\%)、空き地が 19 力所(2.1\%)、行き止まりが 18 力所 $(2.0 \%) 、$ 公 的施設が 10 力所 (1.1\%) である。

各町丁目において、これらのもっとも多い種類を代表的な見える場 所（個所数）として図一 22 に示す。旧城下町では、城壕のある部分 など 4 町丁目で道路が、1 町丁目で駐車場が、そのほかの 30 町丁目 では橋が代表的な水路の見える場所となっている。

このように、水路の見える場所を個所数としてとらえると、道路だ けでなく、橋に代表される点的な場所が浮かび上 がってくる。そのことは田園市街地、計画市街地でも 大きな違いはない。

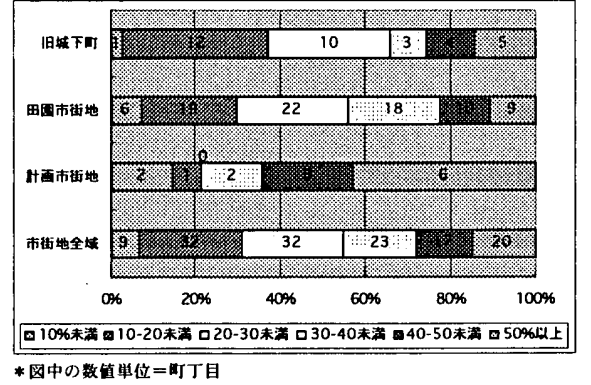

図 -20 町丁目別可視率とその地域比較

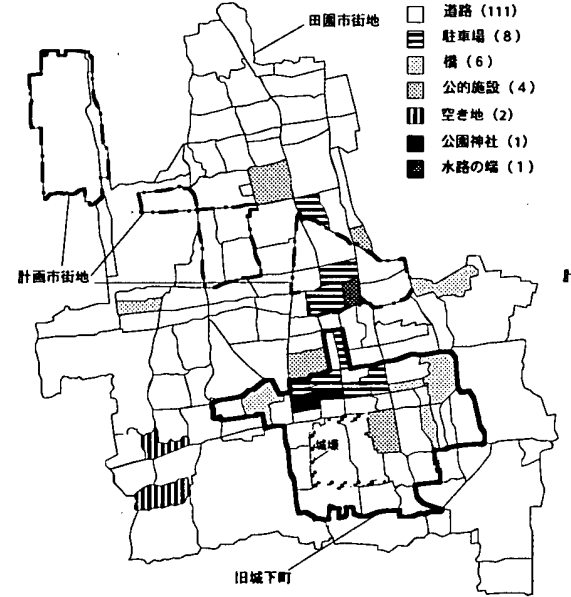

図-21町丁目別代表的な 見える場所（距離数）とその地域比較

\section{6. 佐賀における水路の空間特性と整備の方向に関する考察}

(1) 佐賀の旧城下町には、一定幅の水路を中心としてそれにクリー ク・河川がからんで張り巡らされた水路群がある。このことは、その 周囲に広がる田園地を市街化した田園市街地においても、近年に造成 された計画市街地においても同様である。したがって、水路は神積低 平地に立地する城下町都市佐賀の形成と発展に欠かせない空間的基礎 であることを示していると考えることができる。

(2) これらの水路の空間状況を説明するために、水際の状況、境界の 状況、治川利用の状況の三指標からなる水路空間という概念を設定し て調査を行った。その結果、旧城下町では、公的な空間よりも私的な 空間とともにある水路がほとんどであること、直接的な水路の利用が すくない現在においても水路は空間的に少なからす開かれているこ と、ほとんどの護岸に整備が施されていることから、今後水路の消失 は生じにくいと考えることができる。すなわち、現状において水路は それとしてのみあるのではなく、都市の中に刷り込まれている存在で あるということができよう。

また、田園市街地と計画市街地においても、おおむね護岸整備が施 されているとみることができるが、旧城下町と比べると田園市街地で は水路が空間的により開かれており、計画市街地では道路などの公的 な空間とともにある水路が多いことなど、都市の中での存在形態の違 いを指摘することができる。

(3) 現在の旧城下町の水路は、水路一道路というパターンが交互に繰 り返されて都市の中に配置されている。それは城下町が形成された時 点とくらべて水路の一部の変貌や消失がみられはするが、骨格となる 構成はほとんどかわっていない。したがって、水路はいわば都市の基 礎的ネットワーク、すなわち水網というべきものとして都市の中にあ り続けているということができよう。

(4) 旧城下町の水路には二種類のものが抽出される。この二つの水路 が組み合わされて、旧城下町の水網が形成されていると考えることが できる。一つは、「外に向く水路」ともいうべきものである。ここで は水路の多彩な利用をみることができる。下今宿のそれにはかつての 水運にかかわって荷揚げ場などのための空閑地、水辺の共同のひろば がつくられている。これは外との交流のひろばでもあり、内での利用 のひろばでもある。いま一つのものは、日常生活を通じてかかわる、 「内に向く水路」ともいうべきものである。紺屋町や水ヶ江二丁目会 所小路、下今宿の敷地奥の水路がこれにあたる。水路とのかかわりは 
水を利用する日常生活であり、それも個々の家に直接に水路がとりつ くようになっているから、それを通して近所付き合いがはじまると いった類のものではない。あくまでも個人レベルのものである。水路 はこうした個々をつなぐ役割をもつ。

このような水路が環状につながれば、そこにはおのずと一つの空間 単位ができあがる。しかし、その空間単位が結束の強いコミュニ ティー単位になるということは生じにくい。水路に囲われていること にのみ意味がある。そうであるかぎり水路が環状であるか、線状であ るかを問わないことになる。水路が地区の奥にあって他地区から切り 離し、水辺が内にあって地区を支えているということができる。

(5) 都市の中の水路は二通りの見え方をして存在している。旧城下町 における特徵的なものを橋などの点的な見え方とすれば、その周囲の 田園市街地や計画市街地にはもう一種の見え方、すなわち道路などの 線状の見え方が加えられているということができる。線状の見え方が 旧城下町に無いわけではないが、旧城下町の水路の見える割合が低い ところでは、より点的な見え方が目立ってくると考えられる。そして 注目すべきことは、いずれの見え方であっても、水路の見える割合が 高いところや低いところが混在されつつ、地域ごとにさほどかわらな い一定量の水路の見える場所がみとめられることである。

(6) 以上のことは、これからの水路および都市の整備を行っていく上 で、次のようなことを示唆をしているといえるだろう。1）佐賀にお ける水路の存在は、都市に欠かせない空間的基礎として、今後もしつ かりと位置づけるべきであること。2 ) そのような都市の中の水路の あり方は、旧城下町では水路一道路といった交互の繰り返しとしてあ るように、いわば都市の基礎的ネットワークとして保全すべきである こと。3）一口に水路といっても、都市にとっての意味は異なる。共 同空間や外部との接触空間を生じる「外に向く水路」に配虑すること と同時に、個々の私的な空間とともにあり、社会的居住単位を内に あって支えている「内に向く水路」についても配虑する必要があるこ と。この両者にはそれぞれ異なった整備手法が要求されよう。4)人々 の水路に対する認識は都市及び水路の整備にとって重要なことだが、 水路の線的な見え方とともに、橋などといった点的な見え方について も検討する必要があること。前者はこれまでも取り上げられてきた が、後者は看過されてきた嫌いがある。さらに、5）旧市街地周囲に ついては、田園市街地では空間的に開かれた水路や幅の不定形なク リークへの着目、計画市街地では道路などの公的空間とともにある水 路への着目など、少なくともそのような地域ごとの特徽を考慮する必 要があること。そうすることによってより多彩な水路型生活空間とし て整備されることになろう。

\section{参考文献及び注}

1）上田篤編，マスシテイ研究会著『マスシティ』学芸出版, 1991 年を参照。

2）後藤応寿「地形からみた城下町都市の空間構造に関する研究」(平成 3 年度 佐賀大学卒業研究)、中岡義介・後藤応寿「地形からみた佐賀城下町都市の 空間構造について」日本建築学会大会学術梗概集 F 分冊, pp.539-540, 1992 年、高橋康夫・吉田伸之・宮本雅明・伊滕毅編『図集日本都市史d東京大学 出版会.1993 年を参照

3）中岡義介『水辺のデザインー水辺型生活空間の創造』森北出版, 1986、玉置 豊次郎『日本都市成立史』理工学社,1974 年、及び前揭 2) 高橋康夫他（1993） を参照。

4）前揭 3）中岡義介（1986）、及び、上田篤・世界都市研究会編「水網都市』 学芸出版社 1987 年を参照。

5）佐賀市教育委員会「佐贺の瓄境道産 I \&，1991 年、及び前揭 2）の宮本雅明 の佐賀に関する都市・建築史的な一連の研究成果がある。これらによると、 佐賀は河口テルタや氾篮原に建設された維横無尽に水路を張り巡らされた近 世城下町であり、有明海から入り込む川やその河港、町人地の背後をも平等
に流れる水路網、上流に塭や硬門を用いて取水しそれが物構え越えて城下や 城内導かれいるなど、地形や水系とかかわる特徽が示されている。

6）波多野純「開渠の上水の建設期と城下町設計に果たした役割 一都市施設と しての上水を通して見た城下町設計方法の研究 1 文報告集，第 397 号, 1989 年 3 月。これによると城下町の上水には暗渠と開 渠があり、佐賀は開渠形式の上水が建設されたことなどが詳述されている。

7) 本調查は平成 4 年度河川整備基金助成事業として実施し、その研究成果は 中岡義介編著「迷路としての日本の都市 低平地都市の構造に関する研究一 佐賀におけるケーススタデイ1 1994 年として報告されている。またこれら 成果の一部は、中岡義介・陳光明・松川晴美・西村智美「佐賀における水路

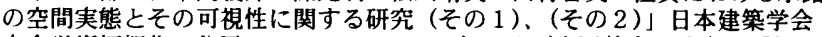
大会学術梗概集 $\mathrm{F}$ 分冊, pp.413-416, 1992 年、及び中岡義介・陳光明「低平 地都市・佐賀における水路の空間的意味に関する研究」佐賀大学理工学部集 報第 22 巻第 2 号, pp.295-304，1994 年、などですでに発表を行っている。 本稿はこれらをもとに、新たに整理分析を加え編集したものである。なお、 本研究で分析の対象とした市街地の状況は、調查の当時から、一部の土地区 画整理事業や部分的な道路整備が行われいるものの、現状においても変化は 少ない。

8）今日の田園地域のクリークは主として農業排水や点在する集落からの生活 排水路と位置づけられるが、農業幹線水路等や上水道が完備されるまでは張 り巡らされたクリークが用水源として使われていた。これらに加え灌娍時期 には、上流部で用水が取水されるために市域南部などの有明海治岸部では灌 溉用水が不足し、佐賀江などの干潮河川（江湖）の逆潮がもたらす河川水 （淡水）を䂛門等の工夫により利用していた。また、かつての旧城下町の堀 川は生活用水路・排水路であるが、これらは下流部のクリークに通じ灌溉用 水としても利用されていた。このように域内の河川 - 堀川・クリーク-江湖 などは用水、排水、貯水機能を合わせもち、璟や桶門などの样々な工夫とと もに成り立つ有機的な水系システムをもつていた。

9）水路の今後を考えるとき、水路は縮小されこそすれ㹡張されることは考え にくく、今ある水路を保ちつつその質を向上させることが大切である。その ためには水路延長ではなく、水路面積の增減を問うことが有効であると考え た

10）一つの町丁目が複数の地域にまたがる場合、もっとも多くの面積をしめる 地域にその町丁目を含めることとした。したがって、蕨密にはかつての城下 町部分之現在の町丁目で構成する旧城下町は異なるが、本稿では近似するも のとして捉えている。

11）河川、堀川、クリークなどはその形成の経緯が大きく異なるといえるが、 現在の都市生活が展開する市街地において、河川は一般の自然河川とは言い 難く、水門や桶門などによって流量が制御されうることなどからも堀川との 違いは明確ではない。クリークについても農業用水としての利用はほとんど なく主として排水や貯水機能を担う。このように現状において用水利用的な 差異が認めにくいことから、本稿ではこれら市街地にある水面を総称して “水路”と呼ぶことした。なお、以下で用いた 4 つの区分はこのような水面 の主として形態的な特徵に基づくものである。

12）調查は、国土地理院撮影の航空写真（昭和 61 年撮影）、および佐贺市作成 の 2.500 分の 1 地形図から水路を取り出し、それを現地で確認して記録し、 図上で計測するという方法でおこなった。(2)、(3)、(4)の水路については、テ ジタイザーを用いて 2.500 分の 1 地形図に落とした面積を測定したが、(1)の

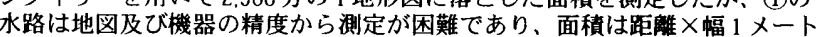
ルとして求めた。

13）水面率は、各町丁目の面積に対するその水路総面積の割合としてもとめ、 平均水面率は町丁目ごとの水面率をもとにした各地域における平均値であ る。また、各町丁目の面積は基本的に佐賀市所有のデー夕を用いており、旧 城下町の総面積は約 388 万 $\mathrm{m}^{2}$ 、市街地全域の総面積は約 2,340 万 $\mathrm{m}^{2}$ である。

14）本稿では、水路治いの土地利用を沿川利用として定義する。

15）調査は、現地調査にて 3 項目の実態を 2.500 分の 1 地形図に記入し、それ らをキルビメーターで距離の測定を行った。測定値の合計は 3 項目について 理論的には同じものとなるはずであるが、実際には測定誤差としての差異が 生じている。なお、調査期間は 1991 年 5 月〜 9月である。

16）地区の選定にあたっては、現在の代表的な地割りパターンA1 であること、 また一部にみられる道路の改変などにより地区が大きく変化していないこと などを考慮して、一般的なものと考えられる3地区を取り上げた。

17）地区の空間構成は、500 分の 1 地形図（佐賀市道路台艮図・1983 年）を現 地調査で補足修正して作成した。道の利用では道路あるいは道路と教地の境 界部分の利用をみるべく、そこにあるものを取り上げた。ただしマンホー ル、電柱などの常態的敖設物は省略した。水路の利用では、水路上や水際、 境界などがどのように利用されているかをみるべく、そこにあるものを取り 上げた。

18）共用栓とは、かつて近隣の数戸が共同で使用する水道であり現在は使われ ていない。一部痕跡のみあるものも含めて記録している。

19）調查は、現地調查によって水路の見える場所を抽出し、その実態を 2,500 分の 1 地形図に記入し、キルビメーターで测定するという方法で実施した。 测定にあたり、橋（大きなものはのぞく）、水路端（水路が道などで行き止 まる部分）、行き止まりについてはそれぞれ一律 $25 \mathrm{~m} 、 25 \mathrm{~m}, 3.0 \mathrm{~m}$ とし、橋 はその両側を計測した。また、水路が町丁目の境界になっているとき、その 水路に架かる橋はそれぞれに振り分けた。水路の見える場所の総距離数は $136.5 \mathrm{~km}$ であり、その内旧城下町では $21.7 \mathrm{~km}$ 、田園市街地では $96.4 \mathrm{~km}$ 、訃 画市街地では $18.4 \mathrm{~km}$ となっている。調査の時期は 1991 年 10 月〜 12月であ る。なお、平均可視率は町丁目ごとの可視率をもとにした各地域における平 均値である。

20）水路の見える場所としての橋は、その両側についてそれぞれ1力所に数え た。道路については、公橋で区切られている間を 1 力所とした。その他の場 所はそれぞれ1力所とした。

2002年12月10日原稿受理，2003年 8 月19日採用決定） 